\title{
O PROBLEMA DA ORALIDADE EM TRÊS TRADUÇÕES DE OF MICE AND MEN, DE JOHN STEINBECK ${ }^{1}$
}

\author{
Johnwill Costa Faria \\ Universidade Estadual de Goiás \\ johnmagister@gmail.com
}

Válmi Hatje-Faggion

Universidade de Brasília

hatjefaggion@yahoo.com

Resumo: No traduzir, uma grande questão envolve a diversidade linguística, quando um escritor resolve dar uma voz mais popular aos personagens de um romance literário, na forma de um dialeto sem prestígio, estigmatizado. Um desses escritores, John Steinbeck, em Of mice and men, apresenta seus personagens com um falar bem típico, que foge ao inglês padrão. Assim, este artigo discute problemas de traduzir a oralidade presente nesse romance, pelo exemplo de três traduções em português, em três épocas distintas: Érico Veríssimo (1940), Myriam Campello (1991) e Ana Ban (2005). Deste modo, observa-se como e por que esses tradutores propõem soluções diferentes para a linguagem dos diálogos.

Palavras-chave: Tradução literária, oralidade, John Steinbeck, múltiplas traduções.

\section{THE PROBLEM OF ORALITY IN THREE TRANSLATIONS OF OF MICE AND MEN, BY JOHN STEINBECK}

\footnotetext{
Abstract: In translation a major question is related to the linguistic diversity particularly when a writer decides to give a more popular voice to the characters of a literary novel in the form of a dialect without prestige,
} 
which is stigmatized. One of these writers, John Steinbeck, in Of mice and men makes his characters speak in a very typical substandard English. This paper discusses problems of translating the orality present in that novel and its three translations into Portuguese in different periods of time by the following translators: Erico Verissimo (1940), Myriam Campello (1991), and Ana Ban (2005). Data show how and why those translators propose different solutions to render the language of dialogues.

Keywords: Literary translation, orality, John Steinbeck, multiple translations.

\section{Introdução}

A tradução literária, ao lidar com todas as diferenças inerentes ao intercâmbio cultural e linguístico, se depara com inúmeros problemas ou dificuldades para o tradutor, quer sejam os relacionados à sugestividade do título, aos nomes próprios, à composição dos personagens e suas características em relação à cultura de chegada, dentre outras questões. A composição dos personagens, além do seu aspecto descritivo, pode lançar mão de outro recurso: os efeitos da língua oral desviante da norma-padrão, com toda a sua riqueza e peculiaridade, que podem caracterizar a informalidade da fala, reflexos momentâneos da emoção, ou mesmo definir o seu perfil, por exemplo, de acordo com a sua etnia, grupo social, nível socioeconômico, gênero e faixa etária. Essas questões podem representar um imenso desafio para o tradutor, quando pelo menos duas possibilidades se apresentam: tentar reproduzir uma variedade linguística estigmatizada ${ }^{2}$ numa outra cultura, mantendo características desse dialeto ${ }^{3}$, ou então, neutralizá-la por meio da norma-padrão da língua.

$\mathrm{O}$ romance Of mice and men, de John Steinbeck, contém em seus diálogos marcas da oralidade dos personagens, num inglês que se distancia da norma linguística padrão, característico do contexto sociocultural em que a história se passa: zona rural da Califórnia, Estados Unidos, década de 1930, no período da Grande Depressão. 
O problema da tradução da oralidade, como será evidenciado, está relacionado a como diferentes tradutores encontram suas soluções, diante da sua perspectiva pessoal e de valores agregados conforme seu tempo, sua cultura e outras variáveis que podem exercer influência sobre o modo de traduzir, como os agentes institucionais.

Para esse fim, serão utilizados neste estudo o romance de John Steinbeck Of mice and men, publicado pela editora Heineman Educational Books, Oxford, s.d. e suas respectivas traduções para a língua portuguesa, todas sob o título Ratos e homens: a primeira tradução, de Érico Veríssimo, publicada em 1940 pela editora Livraria do Globo - Porto Alegre - RS; a segunda, de Myriam Campello, publicada em 1991 pela editora Círculo do Livro - São Paulo, SP; e a terceira, de Ana Ban, publicada em 2005 pela editora L\&PM - Porto Alegre - RS. Essas traduções serão analisadas e comparadas a fim de se verificar as motivações e escolhas de cada tradutor ou dos agentes institucionais, levando em consideração barreiras e limitações de duas culturas diferentes nesse intercâmbio e a dinâmica das línguas.

\section{A tradução de variedades linguísticas e desvios da norma-padrão da língua}

Com relação à tradução de dialetos, Landers (2001, p. 117) afirma que os problemas de traduzir dialetos começam quando se deseja transferir as peculiaridades de dado dialeto para uma dada língua de chegada. Isso parece ficar ainda mais complexo quando se trata de um dialeto desviante da norma-padrão expresso em variações regionais, socioletos, idioletos, registros, tons diferentes etc. Logo, a opinião desse crítico é a de que o dialeto está sempre ligado, geográfica e culturalmente, a um ambiente social que não existe na língua de chegada, e a substituição com um dialeto "equivalente" está fadada ao fracasso. 
Apesar disso, Landers (2001, p. 68) examina e critica a tradução de Samuel Putnam para o inglês da obra Terras do Sem Fim, de Jorge Amado, no trecho: " - Vosmecê me adisculpe, seu coronel, mas nós queria saber, quando é que a gente passa a escritura da terra? (...) Mas vosmecê não se arrecorda que nos vendeu esse pedaço de mata? Pelo dinheiro do contrato de cacau?" (AMADO, 1942, p. 21). Putnam (1945, apud LANDERS, 2001) resolve este fragmento traduzindo-o da seguinte maneira: "You will pardon me, colonel, but we would like to know when we may have the deed to the land... (...) Don't you remember that you sold us that piece of forest? In place of money on the cacao contract?".

Landers considera esta solução como uma violação de tom, pois considera que a fala reproduzida em inglês se assemelha muito mais à de um indivíduo de bom nível escolar - talvez um advogado ou um professor universitário - do que à fala de um agricultor analfabeto, entre outros fatores, pelo uso de may em vez de can, o que contraria o perfil do personagem original, que, na verdade, se mostra como um trabalhador rural no interior do Brasil, cuja fala contém desvios do português padrão.

Esse mesmo autor então faz o que não aconselha ninguém a fazer, e "melhora" o fragmento, obtendo assim, "Beggin' the colonel pardon, but we'd like to know when we can have the deed to the land... Don't the colonel recollect sellin' that piece of forest to us? Instead of the cacao contract?" (LANDERS, 2001, p. 68).

Trata-se de um trabalhador rural analfabeto, mas o registro discursivo utilizado por Putnam soa bastante formal, "civilizado". Por outro lado, a solução de Landers pode até, talvez, ser mais adequada, encaixando o personagem num perfil mais assemelhado ao do texto de partida, no que diz respeito ao seu nível social, ao tom utilizado etc., porém, traduzido por agricultor pobre - devido à sua condição econômica - e também por pobre agricultor - por ser apátrida: não pode ser brasileiro e muito menos de algum país anglofônico. A situação é estranha, pois se vê um personagem da zona rural, com perfil brasileiro, da Bahia, mas falando um inglês 
que o tradutor não deixa claro de onde vem, se é algum dialeto específico, bem localizado no tempo, no espaço e a que grupo social pertence. Jorge Amado deu voz ao seu personagem com um falar típico do português brasileiro com características locais, num dialeto do interior da Bahia. Entretanto, qualquer dialeto da língua inglesa que seja utilizado nessa suposta correspondência da tradução trará sempre consigo algo de exótico ou estranho.

Anthony Pym (2000, p. 69), a respeito da temática em questão, questiona se os marcadores das variedades linguísticas (sotaques, dialetos, socioletos, estilos de classe, e assim por diante) devem ser traduzidos como tal. As respostas que esse teórico apresenta revelam o dilema de se lidar com o assunto, pois esses posicionamentos são, com freqüência, antagônicos, assim como o são as respostas extremas sim e não. No caso da resposta afirmativa, leva-se em conta a importância de transmitir com fidedignidade o que essa linguagem pode representar ao receptor. Quanto à resposta negativa, o argumento apresentado é aquele em que os valores de uma variedade não podem ser mapeados de cultura para cultura.

Pym apresenta três alternativas para traduzir as variedades linguísticas: a opção binária ${ }^{4}$, que consiste em deixar a variedade sem ser traduzida, o que resulta na perda de valor, ou traduzi-la adotando uma variedade enganosa (dada a incongruência entre as culturas e as línguas), e assim, perde-se a verossimilhança; a estância descritiva ${ }^{5}$, a que diz respeito à remuneração do tradutor, o qual não é pago para resolver esses problemas, além do fato de que o leitor, em geral, não se importa com a tradução das variedades e, por isso, o tradutor muitas vezes prefere "consertar" os desvios lingüísticos, conforme Milton (2002); e a liberação existencial ${ }^{\text {, }}$ com o argumento de que não há uma resposta clara para o problema e, portanto, as teorias são incompletas e o tradutor, por si mesmo, fica livre e responsável pelos seus atos ou decisões, de acordo com Lane-Mercier (1997, apud PYM, 2000).

Ao tentar ser conclusivo, Pym afirma que a resposta à questão principal pode parecer fácil: 
quando os tradutores se deparam com os marcadores de uma variedade linguística, o que deve ser traduzido não é a variedade do texto de partida (...). O que deve ser traduzido é a variação, a alteração sintagmática da distância, o desvio relativo de uma norma textual ou genérica. Se estas mudanças podem ser traduzidas, como normalmente é o caso, então se pode dizer que os marcadores foram traduzidos, e, logo, não há mais o que discutir. (PYM, 2000, p. 72) ${ }^{7}$

Para Pym, então parece que o mais importante é deixar os elementos essenciais que constituem a língua de chegada (marcadores básicos do dialeto) como uma variedade ao mesmo tempo diferente da norma-padrão, mas semelhante à função desempenhada pela língua do texto de partida, segundo o provável objetivo do autor e ao seu provável efeito na recepção. Assim, então, um dialeto estigmatizado não é traduzido por outro dialeto estigmatizado, e no texto traduzido na língua de chegada são deixados elementos que caracterizem essa língua segundo a sua função, principalmente, na maioria dos casos, a oralidade expressa nas mais diversas situações, veiculada por agentes caracterizados conforme o significado dessa linguagem, denotando aspectos como classe social, nível de escolaridade, etnia, variações de registro, tom, gênero e idade.

Lenita Esteves, ao discutir sobre as diferenças linguísticas na tradução literária, questiona a eficácia do processo de traduzir uma variedade regional por outra variedade regional, por exemplo, brasileira. Esteves relata que, quando se deseja incorporar essa diferença linguística, para que haja uma correspondência no texto de chegada em português, o personagem deveria ser identificado com alguma região específica. Mas aí surgem as dúvidas, como a questão que diz respeito a que região a língua de chegada seria identificada:

Com uma região brasileira? Caso a tradução fosse levar em conta e tentar reproduzir a diferença regional da fala do tal 
personagem, como fazer isso em português? Que região do país poderia ser escolhida? Qual falar brasileiro ficaria mais adequado/menos estranho nessa caracterização: o caipira de São Paulo? O gaúcho? O nordestino? (ESTEVES, 2005, p. 341)

Esteves contesta a postura defendida pela tradutora canadense Lane-Mercier de substituir um dialeto regional por outro regional, por causa da incongruência ou falta de paralelismo entre as línguas ou pela relativa falta de autonomia dos tradutores, que não fariam suas escolhas livremente. Seu argumento parte do princípio de que nenhuma espécie de dialeto, seja a norma-padrão ou seus desvios, pode ser representada na escrita com precisão e, portanto, num romance, os dialetos apenas seriam uma representação da língua real, viva e presente na fala cotidiana:

ninguém negaria que existe uma abismal diferença entre uma descrição lingüística de uma variante dialetal (seja ela padrão ou não) e sua representação dentro de um romance. O problema estaria justamente em julgar que o autor, ou tradutor, deve, ou pode, representar uma variante dialetal de forma exata e sem distorções. (ESTEVES, 2005, p. 342)

Todavia, Esteves e Lane-Mercier comungam do mesmo pensamento no que diz respeito ao dever do tradutor de se conscientizar dos efeitos do texto que ele produz e, desse modo, a primeira autora sugere uma solução:

mesmo que não goze de tanta liberdade ou autonomia, o tradutor é um produtor de sentidos e precisa estar atento para os efeitos do que escreve. Uma das soluções possíveis é assumir explicitamente o caráter de representação estilizada e, na medida do possível, criar um falar que não 
tente identificar especificamente uma região ou estado. (ESTEVES, 2005, p. 343)

Por conseguinte, a representação de um dialeto na tradução que não configure uma região ou um estado, seria, conforme Esteves, uma opção que, apesar de perder a caracterização dessas identidades específicas, ganharia uma diferença discursiva:

nessa opção, o tradutor estaria perdendo a caracterização regional (que, de qualquer maneira, seria artificial, já que não existe correspondência entre regiões e falares de países diferentes), mas ganharia ao marcar uma diferença discursiva, que com quase toda a certeza é relevante para o texto em questão (senão o autor provavelmente não a teria usado). (ESTEVES, 2005, p. 343)

Isso vem, em termos, ao encontro da argumentação de Pym (2000) exposta aqui anteriormente, o que, embora pareça ser a melhor resposta para o problema, diante das outras opções, merece cautela, dada a complexidade do assunto, e, portanto, não se trata de uma resposta ou solução definitiva.

\section{A linguagem dos diálogos nas três traduções para o por- tuguês de Of mice and men}

Na seção a seguir, serão abordados e discutidos alguns exemplos da variedade linguística empregada por John Steinbeck em seu romance Of mice and men, nos diálogos dos seus personagens nas três traduções para o português. Nos excertos abaixo, esse dialeto da língua inglesa está destacado em itálico.

Steinbeck procurou adequar a linguagem ao perfil dos perso- 
nagens, habitantes da zona rural. Trata-se de um dialeto regional enquadrado numa variedade estigmatizada e que, ao mesmo tempo, é coloquial e rude. Entretanto, cada um dos três tradutores traz um tipo de linguagem diferente em português, tratando o dialeto à sua própria maneira, como se vê no exemplo abaixo, retirado do primeiro capítulo:

'Lennie!' he said sharply. 'Lennie, for God's sake don't drink so much.' Lennie continued to snort into the pool. The small man leaned over and shook him by the shoulder.

'Lennie. You gonna be sick like you was last night.'

(...) 'Tha's good,' he said. 'You drink some, George. You take a good big drink. '(...)

'I ain't sure it's good water, ' he said. 'Looks kinda scummy.' (STEINBECK, s.d., p. 2-3)

- Lennie! - disse êle secamente. - Lennie, por amor de Deus não bebas tanto assim. O outro continuava a refocilar ruidosamente no poço. O camarada inclinou-se sobre ele e sacudiu-o pelos ombros.

- Lennie. Vais ficar doente como na noite passada.

(...) - Que coisa boa! - disse êle. - Bebe um pouco, George. Bebe um gole bem grande (...).

- Não sei se essa água é boa. Parece meio escumosa. (VERÍSSIMO, 1940, p. 8-9)

- Lennie! - disse, ríspido. - Lennie, pelo amor de Deus, não bebe tanto! $\mathrm{O}$ outro continuou a resfolegar no lago. $\mathrm{O}$ homem pequeno inclinou-se e sacudiu-o pelo ombro.

- Lennie, você vai ficar doente que nem na noite passada.

(...) - Tá ótima. Toma um pouco, George. Toma um bom gole (...).

- Não sei se essa água é boa. Parece meio espumosa. (CAMPELLO, 1991, p. 6-7) 
- Lennie! - disse com severidade. - Lennie, pelo amor de Deus, num bebe tanto assim. Lennie continuou a beber ruidosamente. $\mathrm{O}$ homenzinho se abaixou e o sacudiu pelo ombro.

- Lennie. Ocê vai se sentir mal, igual na noite passada. (...) - Foi bom - disse. - Bebe um pouco, George. Bebe um golão. (...)

- Num sei se essa água é boa - disse. - Parece meio cheia de lodo. (BAN, 2005, p. 12-13)

A tradução de Érico Veríssimo utiliza uma variedade linguística mais formal e que resulta em alterações mais substanciais em relação ao texto de partida, pois, apesar de conservar a coloquialidade, os efeitos da fala característica do texto em inglês são suavizados ou perdidos. Myriam Campello, por sua vez, transforma essa linguagem numa variedade que, embora permaneça coloquial e menos formal que a de Veríssimo, ainda assim soa mais "educada" do que a linguagem escolhida por Steinbeck, isto é, os falantes parecem ter um nível educacional maior do que no texto de partida. Ana Ban tenta conservar os efeitos do dialeto dos personagens.

O maior grau de formalidade da tradução de Veríssimo pode ser observado, por exemplo, na sua preferência pelo uso dos verbos na segunda pessoa do singular:

- (...) Lennie, por amor de Deus não bebas tanto assim.

- Lennie. Vais ficar doente (...). (VERÍSSIMO, 1940, p. 8-9).

Campello, por sua vez, em lugar da segunda pessoa $t u$, utiliza uma forma mais geral, você, ou o verbo no imperativo como em bebe, de uma maneira bem comum de falar do brasileiro em situações cotidianas, informais, mas que ainda constitui um meio-termo entre a polidez de Veríssimo e a linguagem mais rude, estigmatizada, dos personagens de Steinbeck: 
(...) Lennie, pelo amor de Deus, não bebe tanto!

- Lennie, você vai ficar doente (...) (CAMPELLO, 1991, p. 6-7).

Por fim, Ban adota um dialeto caipira, reduzindo você para ocê:

- Lennie. Ocê vai se sentir mal (...) (BAN, 2005, p. 12-13).

O dialeto utilizado por Ban fica evidente também pelo uso da palavra num em lugar de não.

Outra passagem serve de exemplo para mostrar diferenças desta natureza entre as três traduções:

'Tell you what,' said the old swamper. 'This here blacksmith - name of Whitey - was the kind of guy that would put that stuff around even if there wasn't no bugs - just to make sure, see? Tell you what he used to do (...) (STEINBECK, s.d., p. 20)

- Vou lhe dizer, retorquiu o velho. - Esse ferreiro, um tal Whitey, era desses camaradas que usam inseticida até quando não há piolhos. Só por precaução, compreende? Pois vou the contar o que êle costumava fazer... (...) (VERÍSSIMO, 1940, p. 40)

- Vou te contar - disse o velho. - Esse ferreiro, um tal de Whitey, era o tipo do sujeito que espalhava esse negócio por aí mesmo sem qualquer inseto. Só por segurança, sabe? Vou te contar o que costumava fazer... (...) (CAMPELLO, 1991, p. 20) 
- Vô te dizê uma coisa - respondeu o velho ajudante. - Esse ferrero aí... o nome dele era Whitey... era o tipo de sujeito que espalhava uns negócio desses aí, memo quando num tinha bicho nenhum... só pra tê certeza, sabe como é? Vô te contá o que ele costumava fazê.......) (BAN, 2005, p. 33)

Nessas traduções, há uma inconsistência por parte de Veríssimo, que utiliza o pronome oblíquo lhe, quando, na verdade, o pronome te ficaria em consonância com a tendência desse tradutor em usar a segunda pessoa do singular - tu. Isso configura, portanto, um desvio da norma-padrão. Já Campello e Ban se valem do pronome oblíquo te, não por esse motivo, mas por causa do uso comum da linguagem coloquial brasileira, que não obriga a concordância de te com $t u$. Nesse caso, te refere-se a você (conforme Campello) ou ocê (conforme Ban), ou seja, há também um desvio da norma-padrão, mas que está de acordo com a linguagem mais informal (oral) escolhida pelas tradutoras.

Outro exemplo sobre diferenças de linguagem se observa no seguinte trecho:

'He ain't no cuckoo', said George. 'He's dumb as hell, but he ain't crazy. An' I ain't so bright neither, or I wouldn't be buckin' barley for my fifty and found (...)' (STEINBECK, s.d., p. 41)

- Não, êle não é maluco - replicou George. - É imbecil como um burro, mas não é louco. E eu também não sou tão vivo, pois si fosse não estava carregando cevada por cincoenta dólares e mais a comida (...). (VERÍSSIMO, 1940, p. 78-79)

- Ele não é maluco - disse George. - É bastante imbecil, mas não é maluco. E eu também não sou tão esperto assim, 
ou não iria carregar cevada por cinqüenta pacotes e mais a comida (...). (CAMPELLO, 1991, p. 38)

- Ele num é tonto - George disse. - Ele é burro feito uma porta, mas num é loco. E eu também num sô tão isperto assim, se não num ia tá aqui carregando cevada pra ganhá cinqüenta pau e a comida (...). (BAN, 2005, p. 59)

Percebe-se que Veríssimo também utiliza linguagem coloquial. No trecho "pois si fosse não estava carregando cevada (...)" (VERÍSSIMO, 1940, p. 78-79), a expressão não estava não segue a norma-padrão, pois o verbo, conjugado no pretérito imperfeito do indicativo, deveria ser colocado no futuro do pretérito ("não estaria"). Tal coloquialismo, no entanto, somente provoca um "decréscimo" no grau de formalidade expresso por Veríssimo, não constituindo essa linguagem, ainda, um padrão estigmatizado. Campello, desta vez, apresenta uma linguagem mais formal, seguindo a norma-padrão. Já, Ban, continua apresentando regularidade quanto ao dialeto que escolheu.

O nível coloquial do texto de partida também se revela pelo uso de expressões idiomáticas e pelo tom da conversa, expressando ironia:

'Sure I've gotta husban'. You all seen him. Swell guy, ain't he? (...) (STEINBECK, s.d., p. 82)

- Claro que tenho marido. Todos sabem. Um homem formidável, não é? (VERÍSSIMO, 1940, p. 151-153)

- Claro que tenho marido! Todos vocês já viram. Sujeito formidável, não é? (CAMPELLO, 1991, p. 73) 
- É claro que eu tenho marido. Oceis tudo já viu ele. Ele é um bom sujeito, né? (BAN, 2005, p. 108)

Assim, a expressão Sure I've gotta husban (ou Sure I've got a husband) encontra nas suas três traduções muita semelhança: “Claro que tenho marido." (Veríssimo)/- “- Claro que tenho marido!" (Campello)/"- É claro que eu tenho marido." (Ban). Uma das diferenças fica por conta do ponto de exclamação acrescentado por Campello, enquanto que Veríssimo e Ban escolhem ponto final. $\mathrm{O}$ ponto de exclamação confere mais expressividade, denotando o humor ou estado psicológico da personagem - entretanto, ele não está presente no texto de partida. A expressão idiomática Swell guy, ain't he?, característica pelo uso do adjetivo swell, de uso informal ou antigo, e o desvio da norma-padrão ain't (contração do verbo to be + not), revela, pelo contexto, uma ironia, traduzida assim: “- Um homem formidável, não é?” (Veríssimo)/“- Sujeito formidável, não é?” (Campello)/“- Ele é um bom sujeito, né?” (Ban). Nessas traduções, a ironia é mantida.

A escolha dos pronomes pelos três tradutores, por sua vez, pode ser assim verificada nas três traduções:

'Uh-huh. Jus' a dead mouse, George. I didn't kill it. Honest! I found it. I found it dead.' (STEINBECK, s.d., p. 5)

- Ahá. Só um rato morto, George. Não fui eu que matei. Palavra! Achei êle. Achei êle morto." (VERÍSSIMO, 1940, p. 14).

- Hã-hã. Só um rato morto, George. Eu não matei ele, juro! Já tava morto. Encontrei ele morto. (CAMPELLO, 1991, p. 8) 
- Não. Só um rato morto, George, num fui eu que matou. Sério! Eu achei. Achei morto. (BAN, 2005, p. 16)

Veríssimo escolhe o tom coloquial e pratica desvios da norma-padrão, como no caso do uso de pronomes do caso reto como objeto direto (Achei êle). Campello repete essa estrutura (ao selecionar não matei ele, ao invés de não o matei); e, ao usar o verbo tava em lugar de estava, assinala o tom coloquial. Ban, apesar de não repetir essa mesma estrutura sintática (ela decide por que matou, achei morto), conserva o estilo do dialeto caipira ao usar as palavras num em lugar de não.

Em linhas gerais, o exame das três traduções, no que diz respeito à linguagem dos diálogos, indica que os tradutores tendem a manter as características gerais do dialeto escolhido em português, cada qual ao seu modo. Apenas se percebe ligeira variação na linguagem de Veríssimo, por vezes formal e cerimoniosa, devido ao uso da segunda pessoa do singular - $t u$, e a conjugação verbal correspondente, mas também coloquial, com alguns desvios da norma-padrão. A linguagem utilizada por Campello e Ban, nesse sentido, é mais homogênea em sua caracterização.

Em todos os exemplos abordados neste estudo, o tom do texto de partida é o elemento que se sobressai e que parece merecer maior atenção por parte dos tradutores, muito embora cada um, em sua subjetividade, tenha feito escolhas tradutórias diferentes quanto ao léxico, aos sintagmas, frases ou a composição geral de cada um dos fragmentos que ilustram cada item. O resultado ou efeito, no todo, apesar disso, representa a manutenção do tom do texto de partida, sem que nenhum dos tradutores tenha causado prejuízo ao significado geral perceptível no texto em inglês. 


\section{Considerações finais}

Muito longe de querer atribuir juízo de valor sobre qual dessas traduções seria a melhor, ou de prescrever como deveria ser tal ou qual solução tradutória, procurou-se, pelo contrário, ressaltar o papel de cada uma dessas reescrituras em relação ao seu próprio contexto referente ao tempo, ao espaço geográfico e à cultura do Brasil, à individualidade de cada tradutor, bem como suas relações com outros agentes, como as editoras e suas motivações e influências sobre a publicação dessas reescrituras.

Tratando-se de uma linguagem que reproduz a oralidade, percebeu-se uma diferenciação por parte de cada tradutor. Mesmo que as três traduções apresentem, de modo geral, aspectos da linguagem coloquial, os dialetos adotados são bem diferentes entre si, variando de um nível mais polido, utilizado por Veríssimo (1940), "decrescendo" em relação à norma-padrão da língua portuguesa, isto é, na coloquialidade do dialeto utilizado por Campello (1991), e na linguagem estigmatizada que Ban (2005) tentou recriar.

A proposta de Pym (2000) sobre a tradução de variedades linguísticas, convergente em muitos aspectos com Esteves (2005), parece ser adequada em muitas dessas situações: não se trata de uma mimesis linguística que preconiza traduzir dialeto por dialeto numa pretensão inalcançável, mas sim, apresentar uma linguagem na tradução que apenas apresente os marcadores essenciais da língua traduzida, caracterizando-a segundo o seu papel desempenhado em seu contexto de origem.

Todavia, a questão de como traduzir uma linguagem estigmatizada, como no exemplo de Of mice and men, permanece fruto de uma discussão sem respostas definitivas. Apesar das diferenças relativas aos dialetos que podem ser escolhidos por cada tradutor e das possíveis perdas ou acréscimos advindas de manipulações, cada tradução cumpre um propósito segundo o contexto/sistema cultural em que foi concebida.

Diante do que foi exposto, percebe-se que a tradução, entendida como reescritura, é um modo variável de reelaborar textos, segun- 
do perspectivas não só diferentes, mas também mutáveis, dinâmicas. Assim sendo, não pode existir "a tradução", mas tão somente "uma tradução possível”, moldada de acordo com propósitos possíveis, mediante forças, desejos e expectativas às vezes atendidas satisfatoriamente ou não, segundo o universo multicultural e complexo da recepção inserida em polissistemas culturais. Logo, existe um processo infinito, incessante, em que cada nova tradução atende a novas expectativas, mas nem por isso pode-se julgar traduções anteriores como inferiores ou menos adequadas, pois cada uma dessas reescrituras atende a propósitos de seu próprio contexto, em sua própria época.

Recebido em 03/04/11

Aceito em 07/05/12

\section{Notas}

1. Ver também Of mice and men, de John Steinbeck: a oralidade como problema de tradução, dissertação de mestrado (FARIA, 2009).

2. Conforme proposta terminológica de Bagno (2005, p. 67).

3. Vide Landers (2001, p. 116-117).

4. “(...) the binary option: Either you leave the variety untranslated (and lose value) or you render it with a misleadingly equivalent variety (and lose vraisemblance): Why should someone in Scotland speak Joual? (so Schogt 1988)" (PYM, 2000, p. 69).

5. “(...) the descriptive stance: Such things are rarely translated, so our task is really to say why. Easy answer: translators are not paid enough to 
solve such problems, and no one really cares anyway (so Milton 1994, 1996)" (PYM, 2000, p. 69).

6. "(...) existential liberation: There is no clear answer to the problem, so the theories fail and the individual translator is free and responsible for whatever they do (so Lane-Mercier 1997) (PYM, 2000, p. 69).

7. "When translators are confronted with the markers of a variety, the thing to be rendered is not the source-text variety (...). The thing to be rendered is the variation, the syntagmatic alteration of distance, the relative deviation from a textual or generic norm. If those shifts can be rendered, as is usually the case, then the markers may be said to have been translated, and no complaint should ensue."

\section{Bibliografia}

AMADO, Jorge. Terras do sem fim. São Paulo: Record, 1942.

BAGNO, Marcos. A norma oculta: língua e poder na sociedade brasileira. $4^{\mathrm{a}}$ ed. São Paulo: Parábola Editorial, 2005.

BASSNETT, Susan. Estudos de tradução: fundamentos de uma disciplina. Tradução de Vivina de Campos Figueiredo. Lisboa: Fundação Calouste Gulbenkian, 2003.

ESTEVES, Lenita Maria Rimoli. Algumas reflexões sobre a ética na tradução. In: Estudos lingüísticos, São Paulo, XXXIV, p. 340-344, 2005. Disponível em: $<$ http://www.gel.org.br/estudoslinguisticos/edicoesanteriores/4publica-estudos-2005/4publica-estudos-2005-pdfs/algumas-reflexoes-618.pdf?SQMSESSID =a3 $\underline{8 f f c 79 c 82 b c b e 561 e 1 c 641326 f d 16 c>}$. Acesso em 2 de maio de 2009. 
FARIA, Johnwill C. Of mice and men, de John Steinbeck: a oralidade na literatura como problema de tradução. 2009, 219 f. Dissertação (Mestrado). Brasília: Universidade de Brasília, 2009.

LANDERS, Clifford E. Literary translation: a practical guide. Clevedon, Buffalo, Toronto, Sydney: Multilingual Matters LTD, 2001.

LEFEVERE, André. Translation, rewriting and the manipulation of literary fame. London, New York: Routledge, 1992.

MILTON, John. O Clube do Livro e a tradução. Bauru: EDUSC, 2002.

PYM, Anthony. Translating linguistic variation: parody and the creation of authenticity. In: VEGA, Miguel A. e MARTÍN-GAITERO, Rafael (ed.). Traducción, metrópoli y diáspora. Madrid: Universidade Complutense de Madrid, 2000, p. 69-75. Disponível em:

$<$ http://www.tinet.cat/ apym/on-line/translation/2000 authenticity.pdf $>$. Acesso em 16 de maio de 2009.

STEINBECK, John. Of mice and men. Oxford: Heineman Educational Books Ltd, s.d. 2005.

. Ratos e homens. Tradução de Ana Ban. Porto Alegre: L\&PM Pocket,

. Ratos e homens. Tradução de Érico Veríssimo. Coleção Nobel. Porto Alegre: Livraria do Globo, 1940.

. Ratos e homens. Tradução de Myriam Campello. São Paulo: Círculo do Livro, 1991. 